The Catholic University of America, Columbus School of Law

CUA Law Scholarship Repository

1967

\title{
William Sampson and the Codifiers: The Roots of American Legal Reform
}

Maxwell Bloomfield

The Catholic University of America, Columbus School of Law

Follow this and additional works at: https://scholarship.law.edu/scholar

Part of the Legal History Commons

\section{Recommended Citation}

Maxwell Bloomfield, William Sampson and the Codifiers: The Roots of American Legal Reform, 11 AM. J. LEGAL HIST. 234 (1967).

This Article is brought to you for free and open access by the Faculty Scholarship at CUA Law Scholarship Repository. It has been accepted for inclusion in Scholarly Articles and Other Contributions by an authorized administrator of CUA Law Scholarship Repository. For more information, please contact edinger@law.edu. 


\section{William Sampson and the Codifiers: The Roots of American Legal Reform, 1820-1830}

by Maxwell BLOOMFiand*

667 HeRe IS NOTHING MORE COMMON than to confound the terms

1 of the American Revolution with those of the late American war," wrote Benjamin Rush in 1787. "The American war is over, but this is far from being the case with the American revolution. On the contrary, nothing but the first act of the great drama is closed."1

The transition from colony to nation involved difficult readjustments in the thinking and behavioral patterns of the American people, and nowhere were the inherent tensions more evident than in the field of law. Prior to the revolution, Americans had willingly accepted the legal principles and practices of the mother country, although modifying them somewhat to suit the more fluid social and economic environment of the New World. But the achievement of political independence from England soon led to demands that all other ties with the former metropolis be severed as well.

Radical agitators in various states thus urged the complete abandonment of the common law during the years from 1783 to 1815. Generally their attacks were motivated by political considerations, becoming more virulent with the rise of the French-oriented Republicans led by Thomas Jefferson. Twisting the British lion's tail in matters legal proved a popular vote-getting device in the early nineteenth century, and alarmed conservatives feared the successful subversion of all law and order.

"It is certainly true," wrote the Federalist lawyer Joseph Hopkinson in 1809, "that very persevering efforts have been made, for some years, in Pennsylvania, by some mistaken men, to bring the Common Law into public odium and disuse." These assaults upon the common law were "gradually ripening into a fatal action. The moment seems to be approaching when the axe will be laid to its root, and its spreading honours prostrated in death." Once the "permanent rules" of Anglo-American jurisprudence were overthrown, Hopkinson anticipated an era of anarchy springing from "the opinions, caprices and prejudices of judges and juries, who

*Department of History, Catholic University of America.

1 Quoted in J. Franklin Jameson, The American Revolution Considered as a Social Movement (1956), p. 20. 
will deal out one measure of justice today and another tomorrow, as humour, favour or affection may incline them."2

Such dark forebodings bore little relation to the real strength of legal radicalism in these early years. While local demagogues might score an occasional victory over the "aristocrats" of the bar and their Tory doctrines, widespread popular sentiment for overhauling the entire legal system was negligible. In part this reflected an absence of serious debate concerning the nature and function of law in a democracy. Partisan politicians found it more profitable to launch personal attacks against their opponents, creating much smoke with little fire. Their efforts led only to the passage in several states of statutes modeled after a New Jersey law of 1799, which forbade members of the bar to cite in court any decision, opinion, or treatise regarding the common law written in England after July 1, 1776. ${ }^{3}$

The renewal of armed conflict with Great Britain in 1812 drove all lesser disputes into the background and ended the first wave of legal extremism in America. Thereafter reformers undertook a new type of propaganda campaign. Promoted by liberal lawyers with no political axes to grind, the Codification Movement of the 1820's sought to awaken the general public to the incongruity between democratic ideals and certain legal realities. For the first time since the adoption of the Constitution, Americans found themselves re-examining the methods and goals of the social order they had created. Newspapers and magazines spread the debate to all parts of the Union and it eventuated in a series of far-reaching legal reforms which stretched across the nineteenth century. A variety of circumstances and individuals contributed to the outcome of the codification effort, as in any large movement; but in its impact upon popular opinion, it owed a peculiar debt to the tireless public relations work of one man-the flamboyant Irish émigré lawyer William Sampson (1764-1836).4

2 Hopkinson, Considerations on the Abolition of the Common Law in the United States (1809), p. 61.

3 Chroust, Rise of the Legal Profession in America (1965), v. 2, p. 54.

4 No adequate biography of Sampson has yet been written. He has described his early career in the Memoirs of William Sampson (1817), providing additional details in his introduction to the American edition of William Henry Curran, The Life of the Right Honorable John Philpot Curran, Late Master of the Rolls in Ireland (1820). For the important American years one must rely principally upon a brief eulogistic sketch prepared by his daughter, Mrs. William Tone, for Richard R. Madden, The United Irishmen, Their Lives and Times (7 vols., 1842-46), vol. 2, pp. 335-388. Sampson's achievements at the New York bar are entertainingly described in Browne, "William Sampson," 8 Green Bag 313 (1896). 
Sampson's career as a legal gadfly began somewhat paradoxically. Born at Londonderry into a family of Anglo-Irish clergymen and landholders, he had every incentive to court favor from the dominant Protestant Establishment. No political or social barriers embittered his young manhood; when he enrolled as a student in Dublin's Trinity College in the 1780's, he was following a path already trod by his father, Reverend Arthur Sampson. And when he later resolved to become a lawyer it seemed only natural to travel to London like other sons of the aristocracy to "keep his terms" at the famous Lincoln's Inn. On his return to Ireland in 1790 he was soon called to the Irish bar and began a promising practice in Belfast, then a bustling seaport as well as the intellectual capital of the country.

Under normal conditions self-interest and a distaste for violent measures would probably have kept Sampson out of radical politics; but the state of Ireland's internal affairs in the 1790's was anything but normal. His debut as a lawyer coincided with an impending crisis in his country's government. Reform measures in such vital areas as land, suffrage, and religion were long overdue. While the Irish Parliament had enjoyed complete control over domestic policy-making since 1782 , its membership was limited to a narrow group of class-conscious oligarchs who, with few exceptions, resisted all efforts at political or social change. Nevertheless change was in the air, especially among the intellectual circles of Belfast, where a dominant Presbyterianism still enshrined the republican spirit of the early covenanters. Nor were more recent sources of inspiration lacking.

"The American revolution had reduced the theories of the great philosophers of England, France, and other countries, into practice," Sampson recalled in his Memoirs; "and persecutors began to find themselves surprised like owls overtaken by the day."5 The American example, with its emphasis upon the natural rights of all citizens, made a strong appeal to Irish liberals, an appeal which was reinforced after 1789 by the more sensational uprising against the old order taking place in France.

Irish sympathy for the Jacobin program found expression in the pages of The Northern Star, a biweekly newspaper founded in Belfast in January 1792 to spread reform ideas throughout Ireland. Sampson was one of the chief contributors to the paper from its beginnings to its final suppression by the government in $1797 .^{\circ} \mathrm{His}$

5 Memoirs of William Sampson, op. cit. supra, note 4, p. 311.

6 Richard R. Madden, The History of Irish Periodical Literature, from the end of the 17th to the middle of the 19th century (2 vols., 1867), vol. 2, pp. 225-235. 
burlesque articles attacked legal obscurantism as a major threat to popular government among his countrymen.

In a widely read satire of 1794 (which was subsequently reprinted in the United States) Sampson ridiculed the harsh criminal laws of the day which the average juror could not understand. He envisaged a trial in which a hurdy-gurdy was charged with criminal libel for daring to play the inflammatory "Ça Ira" along with its other tunes. (The situation was not as whimsical as one might think: the music of a hurdy-gurdy did form part of the evidence used to convict one Thomas Muir of sedition during these years.) Sampson had a field day deflating the pretentious formalities of courtroom procedure. But he struck his most telling blows at the partisanship of Irish judges, in whose hands an ambiguous law could be transformed into a powerful bulwark of the ruling classes. Where the law was oracular (as it too frequently proved to be) the judge usurped the function of both juror and legislator. Trials then became mere puppet shows, with jurors forbidden even to reason about the facts, "but on the contrary they are to hear with the law's ear, see with the law's eye, speak with the law's voice, of which law the court are alone to judge."7

These apprehensions concerning judicial power (later to be revived in a New World setting) stemmed from experience as well as theory. During the years from 1790 to 1798 Sampson appeared in court on numerous occasions to defend clients charged with libel, sedition, and treason. His best efforts counted for little, however, in the face of increasingly repressive legislation and the broad discretion vested in the bench over the conduct of causes and the fixing of punishments. A sense of desperation drove him at last into open rebellion against the government in the shortlived insurrection of 1798 .

"I never was inclined to political contention," he maintained, "and it required strong conviction to move me to sedition. But there are moments, when to be passive, is to be criminal; as when we see a murder committed before our eyes, and do not stretch our hand."8 Originally a proponent of moderate reforms, he came by 1798 to side with Wolfe Tone and the ultranational United Irishmen who demanded complete independence-a revolutionary rebirth -as the only remedy for Ireland's ills. But their projected uprising never got off the ground. In the early spring the government began a systematic roundup of all known agitators, and soon most of the rebel leaders found themselves behind bars.

7 Sampson, A Faithful Report of the Trial of Hurdy Gurdy (1807), p. 10 .

8 Memoirs of William Sampson, op. cit. supra, note 4, p. 311. 
Sampson, long distrusted for his criticisms of official policy, was arrested on suspicion of being in the pay of the French Directory. He hotly denied the charge but never had the chance to disprove it in an open trial. Instead, British authorities arranged a compromise by which all state prisoners were encouraged to secure their freedom through voluntary exile to some European country not then at war with England. Sampson chose Portugal and, after many frustrating delays, reached Oporto in March 1799.

The next seven years (1799-1806) were filled with the uncertainty and danger characteristic of refugee life in any wartime era. Sampson has left a colorful account of his wanderings across the Continent in his Memoirs. While most of his experiences provide only raw material for the romancer, a lengthy sojourn in France (June 1799-May 1805) was of crucial importance to his later professional career.

As a warm supporter of the French Revolution, he was prepared in advance to admire the new institutions reared upon the ruins of the ancien régime. His exile gave him the opportunity to observe at first hand the reconstruction of French society, particularly in the area of law, where the Code Napoleon supplanted the divergent usages of local parlements after March 1804. A personal acquaintance with certain French statesmen and jurists further strengthened his appreciation of the merits of a code system, as opposed to the uncertainties of judicial precedent. Long after his removal to America these French influences would be revived for him in a striking way, for according to his daughter's testimony:

"After the restoration of the Bourbons, several eminent French emigrants, and amongst others Joseph Buonaparte, settled in the United States; most of these united in choosing Mr. Sampson as their legal adviser; some of them had befriended him when an exile, and he now more than repaid the obligation."

The British Government, with which Sampson had maintained an acrimonious correspondence since the beginning of his exile, at last granted him permission to emigrate to the United States in May 1806. Soon after his arrival in New York he was admitted to the local bar, which was strongly federalist and anti-revolutionary in character. Building a practice in such an environment required discretion, and Sampson generally avoided direct involvement in partisan politics. He found it easier to remain detached, because he believed that most political differences in America were minor ones. Nevertheless by 1812 his Jeffersonian sympathies did lead him to publish anonymously two small pamphlets defending Republican

9 Madden, op. cit. supra, note 4, p. 374. 
policy and lashing out at England's violations of international maritime law. ${ }^{10}$

Such rare confessions of political faith counted for little beside a growing interest in reforming the entire structure of American law. This ambitious project came to seem more and more imperative as Sampson found himself re-engaged in the old struggle to protect the civil liberties of his clients against the harsh demands of English precedent. A string of dramatic criminal trials soon established his reputation as a brilliant defense attorney, while his skill in shorthand reporting enabled him to publish complete accounts of the most interesting cases in which he took part.11 The courtroom became his forum during the years from 1807 to 1822 , and he performed there with maximum effect in such celebrated actions as the Case of the Journeymen Cordwainers of the City of New York (1809).

This was one of the earliest important attempts to establish the legality of the closed shop in America. A group of workers had formed an association to improve their lot and sought to enforce a demand for higher wages through strike activity. While no American statute prohibited such conduct, it stood condemned as an illegal conspiracy at common law. Should English doctrine on this point control the decision of a New York judge? Sampson argued convincingly that it should not.

The common law, he pointed out, had never been adopted in full by the American colonies. Even Blackstone acknowledged that the colonists took with them only those legal precepts and institutions suited to conditions in the New World. Now that independence had been achieved, it was of vital importance to guard against any foreign doctrines that might impair the growth of a democratic society. English conspiracy statutes, directed against working class organizations, had no place in a free America.

"We might as well prevent parents from conspiring to marry their children, indict landlords for refusing to let their house at the usual rents, or merchants from following the rates of the markets," Sampson declared. He attacked the class bias of English legislators and judges, whose reactionary pronouncements were held in superstitious awe by American jurists. A blind adherence to common

10 Trial of Capt. Henry Whitby . . . also, the trial of Capt. George Crimp (1812).

11 For an evaluation of Sampson's importance as a pioneer court reporter, see Charles Currier Beale, "William Sampson," Proceedings of the New York State Stenographers' Association at the Thirty-first Annual Meeting, held at Albany August 23 and 24, 1906 (Albany, 1906), 20-42. 
law precedents could undermine the very ideals for which the Revolution had been fought, as in a recent workmen's case in Philadelphia where

“. . . his honor said it was improper to inquire whether or not the application of the common law to our concerns would operate as an attack upon the rights of man. . . . But the constitution of this State is founded on the equal rights of men; and whatever is an attack upon those rights is contrary to the constitution. Whether it is, or is not, an attack upon the rights of man, is, therefore, more fitting to be inquired into, than whether or not it is conformable to the usages of Picts, Romans, Britons, Danes, Jutes, Angles, Saxons, Normans, or other barbarians, who lived in the night of human intelligence. . . . The more I reflect upon the advantages this nation has gained by independence, the more I regret that one thing should still be wanting to crown the noble arch-a NATIONAL CODE."12

Sampson's arguments failed to convince the court, which refused to consider the reasonableness of common law doctrines adopted as the basis of New York jurisprudence by the framers of the state constitution of 1777. Despite the local interest aroused by his cases, he remained a minor critic of the law-indistinguishable from other shadowy agitators in Ohio, Kentucky, and Pennsylvania - until the publication of his Discourse on the Common Law in 1823.

This address, commissioned by the New York Historical Society, contained the most sweeping indictment of common law idealism ever written in America. By tracing legal thought back to its origins in the customs of barbaric German tribes, Sampson sought to dispel forever the myth that a golden age of English jurisprudence had existed prior to the Norman Conquest. This was no exercise in pedantry, for the "Saxon idols" still held a firm place in American legal folklore. Even such a bitter opponent of Blackstone and Mansfield as Thomas Jefferson professed a sentimental loyalty to the "pure" institutions and practices of the Saxon era. ${ }^{13}$

But what relevance had the Saxon experience for nineteenthcentury America? They were mere savages, Sampson insisted, less civilized than the Iroquois Indians of the New World. Of modern commercial transactions they had no inkling; their criminal laws

12 The Case of the Journeymen Cordwainers of the City of NewYork, 1 Yates's Select Cases 142 (N. Y. 1811).

13 For Jefferson's ideas on legal history, see Waterman, "Thomas Jefferson and Blackstone's Commentaries," 27 Ill. L. Rev. 629 (1933). 
did not progress beyond the brutalities of the lex talionis; and there was little evidence to suggest that they originated the jury system, which they seldom employed in comparison with the trial by water or red-hot ploughshares. Yet their primitive codes, with all their deficiencies, proved more humane than the system imposed by their Norman conquerors. It took centuries thereafter for judges to reestablish the rights of the individual citizen by resorting to a series of awkward fictions which made the law unintelligible to the average man.

Was it not high time to discard such mummery and pretense, and place the law upon a rational and scientific footing? "The wellbeing of society requires that a subject of such vital importance should be brought to the test of reason in the open light of day," Sampson urged. "Having adopted the common law of England, so far as it is not repugnant to our constitutions, we have a mighty interest to know clearly what it is, and from what stock it comes. We must either be governed by laws made for us, or made by us."14

History demonstrated that no part of the common law tradition deserved special veneration; rather every doctrine should be tested by the principles of "natural reason, universal justice, and present convenience."15 In championing the cause of innovation, Sampson appeared to be following a course marked out by earlier reformers; but in fact a wide gap separated him from the Jeffersonian agitators of the pre-1812 years.

The Jeffersonians had attacked the law as an instrument of class domination in America. They sought to arouse the feelings of backwoods "republicans" against a privileged establishment of urban lawyers and judges, whose mastery of abstruse legal doctrines enabled them to promote the ends of a wealthy elite at the expense of the democratic masses. Such partisan tactics proved most effective in frontier areas such as Ohio or the western parts of Pennsylvania, where the labels "Republican" and "Federalist" became interchangeable with "jacobin" and "aristocrat" in the popular mind. ${ }^{16}$

14 Sampson's Discourse, and Correspondence with Various Learned Jurists, upon the History of the Law (1826), p. 32.

15 Sampson, op. cit. supra, note 14.

16 William T. Utter, "Saint Tammany in Ohio: A Study in Frontier Politics," Mississippi Valley Historical Review, vol. 15 (Dec. 1928), 321340; Utter, "Ohio and the English Common Law," Mississippi Valley Historical Review, vol. 16 (Dec. 1929) 321-333; Surrency, "When the Common Law Was Unpopular in Pennsylvania," 33 Pennsylvania B. A. Q. 291 (1962) ; Chroust, "The Dilemma of the American Lawyer in the Post-Revolutionary Era," 35 Notre Dame Law. 48 (1959). 
But it was precisely this element of class antagonism which Sampson and his adherents rejected in the 1820's. They worked for reform within the legal profession, looking to the scholar rather than the demagogue to carry through their program. Sampson thought of himself as a latter-day Luther, called to purge the law of its superstitious and irrational features so that it might be reestablished on a basis of sound principles intelligible to the average man. Far from desiring to uproot accepted doctrines recklessly, he conceded "that the English reports contain, amidst a world of rubbish, rich treasures of experience, and that those of our own courts, contain materials of inestimable worth, and require little more than regulation and systematic order."17 The task of culling useful precepts from a mass of conflicting court decisions could only be entrusted to the legislature, however, because judges were disinclined by temperament and training to challenge past authorities.

Sampson pictured the judiciary as slaves of precedent. Whenever a case arose, the doctrine of stare decisis required that a judge suspend his own views and seek instead to fit the facts into some line of previously reported opinions. Since these opinions were both voluminous and at variance with one another, a litigant had no way to predict the outcome of his case. Even where the circumstances proved unique, and a judge found himself compelled to render a verdict on the basis of his own beliefs, one litigant fell victim to the announcement of every new rule.

Judicial policy-making, by its very nature, could lead only to arbitrary and highly personal results, yet Sampson was careful to avoid imputing any sinister or undemocratic motives to the judges themselves. It was the system that was at fault, he insisted, a system adapted to the needs of a society in which the masses could neither read nor write and had therefore to rely upon the haphazard decisions of the bench to determine their lawful rights. But in America, where popular education was the rule, each citizen had an obligation to study and comprehend the law for himself. A legislative code modeled upon the Code Napoleon would provide comprehensive guidelines for both lawyers and laymen, and would insure popular control over any future changes of policy.

To reduce the amorphous bulk of the law to a system of scientific axioms would prove an immense undertaking, of course, but the first steps in the process had long been taken. Most states periodically revised and digested their written statutes; why not complete the picture by systematizing court decisions as well? The times were uniquely favorable for such an experiment. While European nations still suffered from wars and domestic tyranny, the

17 Sampson, op. cit. supra, note 14, p. 38. 
United States had entered upon an era of unprecedented peace and prosperity, in which the fierce party feuds of the Jeffersonian years seemed buried forever. Citizens of all political faiths could now unite behind the labors of enlightened jurists who should reform the law with a "tender, patient, kindly, and experienced hand."18

Sampson's Discourse was widely reported in the newspaper and periodical press of the time, and created a storm of controversy among reviewers. While no purely legal journals existed in America in 1824, lawyers contributed extensively to more general publications, which always contained a healthy smattering of articles dealing with current trends and problems in the law. Henry D. Sedgwick, writing for Boston's influential North American Review, praised Sampson's bold attack upon judicial servility to "precedents not consonant to the spirit of the age" and urged that "at least some of the larger and more wealthy states of the Union should cause their laws to pass under a general revision, and to be formed into written codes." Conservative reviewers in Philadelphia and New York, on the other hand, denounced the Discourse as shallow satire and suggested that any visionary tampering with the law would destroy one of the strongest bonds of union between the states. ${ }^{19}$

As popular interest in the codification question mounted, Sampson began a new publicity campaign designed to point up the practical advantages of the scheme. For two years (1824-1826) he maintained an active correspondence with politicians and jurists throughout the Union, spreading his ideas through local newspapers and national magazines. ${ }^{20}$ The cream of this correspondence reappeared in book form in 1826, by which time legal reform had become a commonplace topic of discussion in literary journals and a source of increasing comment among foreign observers. ${ }^{21}$

18 Sampson, op. cit. supra, note 14, p. 36.

19 Henry D. Sedgwick, "The Common Law," North American Review, vol. 19 (Oct. 1824) 427, 430; "The Common Law," Port Folio, vol. 17 (Apr. 1824), 296-299; "The Common Law," Atlantic Magazine, vol. 1 (May 1824) 23-30; "On the Substitution of a Written Code, in the place of the Common Law," Atlantic Magazine, vol. 1 (Aug. 1824) 283-298.

20 Sampson's principal American correspondents included: Thomas Cooper and Gov. John L. Wilson (S. C.); Charles Watts (La.); Sen. Isham Talbot (Ky.); and George M. Bibb (Wash., D.C.). The debate over codification may be traced through such varied publications as: New York American; National Intelligencer (Wash., D. C.); New York Evening Post; Charleston Mercury; National Advocate (N. Y.) ; North American Review; Atlantic Magazine; and United States Law Journal.

21 See, for example, C. S. Daveis, "Common Law Jurisdiction," North American Review, vol. 21 (July 1825) 104-141; "Verplanck's Essay on Contracts," New York Review and Atheneum Magazine, vol. 2 (Jan. 
Sampson and his supporters were ardent Francophiles who looked to the Code Napoleon as a model for American legislators. In their eyes, the French experience demonstrated the limits of improvement possible under a code system. While no set of general principles could answer all human problems, the wisest precedents of the past could be summarized in definitive fashion as a guide to the future. Then, noted the South Carolinian jurist Thomas Cooper, "the labor of reading and of citing the cases which form the basis of the principles enacted ... will have been taken away, and if much labor still remains, much has been saved." Far from acting as a deterrent to further social change, every code would be revised from time to time to incorporate new rights and remedies. "But is it nothing," Cooper argued, "that we have, or can have if we please, a new starting place every half century, leaving behind us the accumulated rubbish of years' proceedings?"22

Such labor-saving considerations had special meaning for practicing lawyers in the 1820 's, who found themselves confronted with an ever-increasing mass of reported decisions. In 1824 Caleb Cushing noted that the number of volumes of American reports alone had leaped from eight to 198 during the previous twenty years. ${ }^{23}$ Codification provided at least one answer to the rising cost of a lawyer's library, as well as the major delays he encountered in preparing and pleading a case.

But the general public would reap the greatest benefits under a code system, for the law would cease to be a mysterious science beyond the ken of the masses. Once reduced to fixed moral principles, its methods and objectives could be appreciated by the average layman, who would find the printed code an indispensable textbook of social ethics. A wiser and more responsible citizenry had already

1826) 106-125; Henry D. Sedgwick, "Correspondence on the History of the Law," North American Review, vol. 23 (July 1826) 197-201; "Reviews" (Sampson's Discourse and Report from New York Commissioners), United States Literary Gazette, vol. 4 (Aug. 1826), 345-348; "Aperçu de la Situation Intêrieure des Etats-Unis d'Amerique et de leurs Rapports Politiques avec l'Europe. Par un Russe," Monthly Review (London), III n.s. (Sept. 1826), 45-59; Bonnecase, La Thémis (18191831): Son Fondateur, Athanase Jourdan 158 (2d ed. 1914). The codification controversy also furnished material for several lively satires, including the novella "The Perfection of Reason" in James $\mathrm{K}$. Paulding, The Merry Tales of the Three Wise Men of Gotham (rev. ed., 1839), pp. 105-169; and "Letter of Levinz Comberbach," New York Review and Atheneum Magazine, vol. 2 (Feb. 1826) 213-216.

22 Sampson, op. cit. supra, note 14, p. 53.

23 Caleb Cushing, "Law Reports," North American Review, vol. 18 (Apr. 1824) 377. 
developed in France following the enactment of the Code Napoleon, while in Louisiana, where a civil code had recently gone into effect, the transplanted New York attorney Charles Watts observed: "The planters and well informed men have the code in their hand, and discuss it as a branch of politics; while, on the contrary, the community here (in New York) are involved in Egyptian darkness. ...."24

If laymen were to play a more meaningful role in legal deliberations, however, that did not imply the destruction of the professional bar. The codifiers compared the law to a skilled trade whose practitioners required specialized talents and training. Could every man be his own cobbler? they asked. Obviously not. Yet the principles of shoemaking were known to all, and a customer could readily detect the difference between a good pair of shoes and those of inferior quality. So it would be with the law: a thorough grounding in basic principles would enable the average man to exercise a healthy check upon legal fraud and mysticism, as the Reformation had established popular control of religion without lessening the need for trained ministers. Codes could never produce a lawyerless utopia, for litigation was rooted in the selfish nature of man. But the caliber of the bar would be immensely improved under a code system which would eliminate the uncertain precedents and archaic technicalities that played into the hands of the shyster class of common law pleaders.

In emphasizing the limited aims of their reform program, Sampson and his colleagues were seeking to dissociate themselves from the radicalism of Jeremy Bentham, the English proponent of codes whose propagandist labors for more than thirty years had made his name synonymous with the codification cause in both Europe and America. Bentham was an eccentric reformer who cherished a rather personal hatred of the English judiciary and of what he regarded as the sentimentality of the natural rights school of jurisprudence. In his view a citizen could claim only such rights as were guaranteed to him by positive legislation. To speak of imaginary states of nature conferring inalienable liberties upon the individual was absurdly romantic. Personal freedom could not exist without specific governmental sanctions. Only a code of laws defining in detail the scope of individual action could protect the average man from designing politicians and judges. ${ }^{25}$

Bentham looked upon such written codes as the sole determinant

24 Sampson, op. cit. supra., note 14, p. 87.

25 Paul A. Palmer, "Benthamism in England and America," $35 \mathrm{Am}$. Pol. Sci. Rev. 855 (1941). 
of rights and duties within a state. They were to cover every conceivable problem that might arise among men, embodying solutions in the form of general principles that all men might grasp. An eighteenth-century faith in the inherent rationality of mankind led Bentham to insist also that each article of a code be followed by an explanatory justification, so that citizens might not only know what the law was, but why it had been framed. On this account he sharply criticized the Code Napoleon, alleging that if the true nature of many of its provisions had been revealed to the French people, they would have rebelled against the Corsican's arbitrary rule..$^{26}$

The American codifiers, on the other hand, considered the brevity of the French code one of its prime attractions. Nor were they ready to abandon the natural law philosophy of John Locke which had inspired the revolutionists of 1776 and now held sway over their sons. Lockean intellectual tradition and French legislative practice formed the twin foundations upon which Sampson and his adherents proposed to erect their codes, which should not supplant pre-existing rights but rather supplement and strengthen them.

The opponents of codification, deprived of a favorite whippingboy in Benthamite radicalism, turned their full energies toward discrediting the Code Napoleon. "What kind of legislation is this for all the various and multiform concerns of a whole community?" demanded a writer in the Charleston Mercury of July 28, 1825.27 The French experience only demonstrated the futility of trying to compress human behavior into rigid categories. Without a plethora of judicial interpretations the stifling restraints of the code would long since have acted to check economic and social progress in France. As it was, critics charged that many articles were being superseded by court decisions and that in twenty or thirty years such judicial glosses would constitute the sole source of authority for Frenchmen. ${ }^{28}$

To counter these attacks, which struck at the heart of his program, Sampson appealed directly to one of the most distinguished practicing lawyers of France, André Dupin, for a first-hand account of legal conditions in his country. Dupin's reply, which was published in both the United States and England, supplied an indispensable link in the codification argument.

26 Bentham, Supplement to Papers Relative to Codification and Public Instruction (1817), p. 126. See also Chilton 'Williamson, "Bentham Looks at America," 70 Pol. Sci. Q. 543 (1955).

27 Sampson, op. cit. supra, note 14, p. 59.

28 "On the Substitution of a Written Code, in the Place of the Common Law," op. cit. supra, note 19, pp. 287, 295. 
After rehearsing the advantages which France derived from abolishing divergent customs in favor of a uniform national code, Dupin observed:

"It is not true, sir, that the authority of precedents has at all prevailed against the text of our codes, nor that we are threatened, in the most distant manner, with the disappearance of the letter of the law under the heap of interpretations. In every discussion, the text of the law is first resorted to, and if the law speaks, then non exemplis sed legibus judicandum est. If the law has not clearly decided on the particular case under discussion, doubtless, it being silent or deficient, the defect is supplied by the judges; but where is the system in which the judgments have not necessarily furnished the complement of legislation."29

Judicial construction of doubtful statutes remained a far cry from judicial control of policy-making, such as existed in common law countries, where the bench regulated the tempo and nature of legal change through "the exercise of arbitrary power."30

Dupin confined his remarks to the French codes, voicing only a hesitant faith in America's readiness for a similar experiment. But from another Frenchman, Count Pierre François Réal, came enthusiastic support for Sampson's labors, coupled with some practical suggestions for setting up and working with a code commission.

Réal was uniquely qualified to offer such advice. As a jurist and personal friend of Napoleon, he had played a major role in drafting the French codes. His unshakeable loyalty to the Emperor, whom he served as prefect of police during the Hundred Days, caused him to be banished from France in 1815 by the restored government of Louis XVIII. Thereafter he emigrated to America and settled in upstate New York, from which refuge he wrote to Sampson in 1824, urging

"Do as we did, but do it better, profiting by our mistakes. Let four or five good heads be united in a commission, to frame in silence the project of a code. It is not so difficult a task. It is only to consult together, and to select ... . what is best from your best authors. You have ample materials. We had Pothier always in our hands, and above all his Treatise on Obligations. We compared and weighed; we tried to settle what was in doubt, and fix what was uncertain, and were often guided by his solutions, which we did little more than reduce into articles. . . .

29 "Letter on the Napoleon Code," United States Review and Literary Gazette, I (Nov. 1826), 127. 30 "Letter on the Napoleon Code," op. cit. supra, note 29, p. 128. 
As long as nothing is written, nothing will be done; but you gain something the moment that you have a written text for the groundwork of your discussions, how imperfect soever it may be at first. Our code was far from being adopted, as it was originally proposed in the entire. I doubt whether one hundred articles were preserved in the form in which they were presented. It will require ardent hearts, and cool heads, and resolved industry, for such a work. With these, I think, you will not fail of complete success." 31

With the publication of his Correspondence with Various Learned Jurists in 1826, Sampson abandoned his propagandist activity. He had reached the age of sixty-two and his health, never very robust, began to decline perceptibly until his death a decade later. While he continued to practice law on occasion into the early 1830 's, he resisted all temptation to re-engage in controversial public debate of any kind. "In late years," wrote his friend William Macneven in January, 1837, "his habits were so retired, and his occupations so domestic, that his name seldom came before the public, and his society was only enjoyed by a small circle of intimate friends." 32

Sampson's retirement involved no desertion of his fellow reformers, for he had already accomplished his objectives. He never aspired to draft a code himself, being content to arouse the general public's interest in such an innovation. And who could deny that the public was interested by $\mathbf{1 8 2 6}$ ? In Louisiana a civil code and a code of practice had been adopted by the legislature the previous year; New York had commissioned three lawyers to review the inadequacies of her existing statutes as a possible first step in the direction of a general code; significant codification movements were afoot in Pennsylvania and South Carolina; the American bar in general was sharply divided over the issue, with influential spokesmen arrayed on either side; and Sampson's arguments were even being reprinted and studied in England, where they offered encouragement to a rising band of English legal reformers. Codification appeared to be the wave of the future to many informed commentators, such as William H. Gardiner of the Massachusetts bar, who predicted to readers of the North American Review in January, 1827: "Codes are to be proposed, discussed, assailed, defended,

${ }^{31}$ Sampson, op. cit. supra., note 14, pp. 66,191 . A brief but colorful account of Réal may be found in Clarence Edward Macartney and Gordon Dorrance, The Bonapartes in America (1939), pp. 123-124. p. 387.

32 Quoted in Madden, The United Irishmen, op. cit. supra, note 4, 
throughout the union; and we look to see the day, when codifiers and anticodifiers will wage a war as fierce and interminable, as that which raged of yore between the Doctors of Admiralty and his Majesty's servants of King's Bench."33

Within a decade, however, the energies of the codification party were either neutralized or diverted to other ends by the advent of Jacksonian Democracy. The most influential legal reformers of the 1830 's, such as Robert Rantoul, resurrected the old shibboleths of monopoly and class privilege, damning not only the common law but the common lawyer as well. Popular distrust of the expert during the Jackson years militated against the success of any scheme to employ salaried professionals to reconstruct the content of the law. ${ }^{34}$ Yet the undemocratic features of the existing system seemed to cry all the more urgently for correction.

The Jacksonians resolved their dilemma by extending the spoils system from politics to jurisprudence. Instead of attempting to reshape abstract legal doctrines, they concentrated on getting the right sort of men into judicial posts. Mississippi led the way through a provision in her new Constitution of 1832 that all judges should be elected to office for short terms. Soon a majority of states followed her example, abandoning the older practice by which judges were appointed to the bench for life. ${ }^{35}$

Along with this assault upon the judiciary went a vigorous drive to "democratize" the bar by opening legal practice to all comers. Jacksonian orators asserted that every man had a natural

33 W. H. Gardiner, "Revision of the Laws of New York," North American Review, vol. 24 (Jan. 1827) 194; Sampson, op. cit. supra, note 14, pp. 74, 103, 159; "Codification of the Laws of the United States of America," 2 Jurist (London) 47 (1828). In Louisiana, stronghold of French legal thought, code commissioners had been appointed as early as 1821. Here Sampson's publicity campaign tended to provoke a vigorous anti-code reaction by 1826 . See Sampson, op. cit. supra., note 14, p. 162. The most famous Louisiana codifier, Edward Livingston, was an avowed Benthamite; significantly his Criminal Code, which sought to approximate Bentham's standards, was not adopted by the Louisiana legislature, while a Civil Code and Code of Practice, based upon French models, went into effect in 1825. Smith, "Edward Livingston and the Louisiana Codes," 2 Columbia L. Rev. 24 (1902).

34 A good example of Rantoul's polemics may be found in his "Oration at Scituate" (1836), reprinted in Memoirs, Speeches, and Writings of Robert Rantoul, Jr., ed. Luther Hamilton (1854), pp. 251-296. See also Arthur M. Schlesinger, Jr., The Age of Jackson (1950), pp. 322-333; and Chroust, Rise of the Legal Profession (1965), vol. 2, pp. 59, 69.

35 Blackard, "The Demoralization of the Legal Profession in Nineteenth Century America," 16 Tenn. L. Rev. 318 (1940). 
right to follow any business, profession or calling. Pursuant to this theory state legislatures passed laws in the 1830's and 1840's which abolished all qualifying tests for admission to the bar and made every man in truth his own lawyer.

Massachusetts set the example in an act passed in 1836 which declared that if a man was of good moral character and had read law for three years in an attorney's office, he was automatically entitled to practice before the state courts. Other states-including New Hampshire (1842), Maine (1843), Georgia (1847), Wisconsin (1849), and Indiana (1851)-eliminated even the clerkship requirement and recognized every "citizen" or "resident" as a bona fide lawyer. ${ }^{36}$

The layman also wielded new power as a juror during these years. In many jurisdictions judges were forbidden to comment on the evidence during a trial or even to charge the jury except in terms proposed by counsel. Lawsuits became more than ever tests of forensic skill, with judges reduced to the status of passive spectators and jurors weighing the evidence with little guidance outside of their own intuitions..$^{37}$

In such an egalitarian atmosphere the professionalism of the old-style codifiers was foredoomed to defeat. Yet their program suffered also from internal contradictions which no overall assessment can fail to acknowledge. Logically Sampson and his colleagues fell between two stools. They preached emancipation from English legal tutelage in the name of a militant nationalism, while clinging to an eighteenth-century faith in the efficacy of unvarying moral principles. To extol the uniqueness of American conditions was one thing; to bury national peculiarities within general formulae was something else again. For code provisions, once formulated, tended to represent absolute values, largely independent of time and space. And in challenging the common law tradition reformers encountered a line of defense much better attuned to the romantic xenophobia of the age.

Champions of the judiciary argued convincingly that court decisions mirrored the changing mores of a people more faithfully than uniform laws, which took account only of extreme variations in popular attitudes or behavior. Litigation, on the other hand, served as an accurate barometer to measure the slightest fluctuations in the national character. As customs altered within a state, the common law, grounded upon the collective experience of the

36 Blackard, op. cit. supra, pp. 314-316.

37 Griswold, Law and Lawyers in the United States (2d ed. 1965), p. 19. 
citizen body, altered in turn. ${ }^{38}$ Such considerations appealed to the jingoism of post-1812 America; coupled with the fact that most state legislatures in the 1820's and 1830's were still dominated by lawyers trained in the black-letter school, they posed a formidable barrier to the ultimate success of any program of general codification.

Yet if the codifiers had lost their major battle by the mid1830 's, in one important respect they won the war. Sampson's strictures against the technicalities of common law pleading and the hoary fictions of Anglo-American property law set in motion a chain of limited reforms which vitally altered the shape of American jurisprudence by the end of the century. As a direct result of his labors, the New York legislature passed a statute in 1828 which revolutionized the real property law of the state, forming in effect a partial code. ${ }^{30}$

Other states in turn began to explore the possibilities of systematizing certain branches of their law by taking into account not only prior statutes, but related judicial decisions as well. The new trend assumed major proportions after 1848, when New York abolished the intricate common law rules of pleading and practice in a Code of Civil Procedure which was soon adopted by twenty-three other states and territories.40

Under the guise of legislative revision the codification movement achieved respectability and Sampson and his adherents slipped into the mainstream of the American reform tradition. "A few years ago," declared the influential American Jurist in April, 1835

“. . . codification had a direful import to the conservative party in jurisprudence; and not wholly without reason; since some of its early champions were sturdy radicals in legal reform. In this view codification was another name for juridical revolution. ... But the alarm has subdued ... and the doctrine seems to be now acquiesced in, by a general consent, that a code must be more a digest and arrangement of existing laws, than a body of new enactments made per saltum. . . . The substitution of the terms revision and consolidation of statutes, for that of codification, has contributed, in no small degree, to the change of thinking on this subject. ..."

38 N. Haven, "English Common Law Reports," North American Review, vol. 21 (Oct. 1825) 377-388; N. Haven "On the Substitution of a Written Code, in the Place of the Common Law," North American Review, vol. 21 (Oct. 1825) 288-292, 295.

39 Warren, $A$ History of the American Bar (1911), p. 525.

40 Warren, op. cit. supra, note 39 , pp. 528-539. 
Partial codiflcation thus emerged as the answer of the professional bar to the mounting clamor for changes in the law after 1828. As laymen struggled to democratize the bench, lawyers worked to re-establish confidence in judicial integrity by eliminating the most glaring anachronisms of common law doctrine. Out of the ferment of these years developed a continuing reform impulse which restructured American law in significant ways through the rest of the century. The process was gradual and piecemeal, but it did establish a more realistic balance between legal traditionalism and the expanding needs of a modern democracy. And though many important problems remained untouched by 1900 , those at least which were earmarked for correction by the debates of the 1820's had received in the interim a sound and enduring settlement at the hands of common law lawyers and judges. 